\title{
Influence of Reduction of Cytoplasmic ATP on Catecholamine Secretion from Intact and Digitonin-Permeabilized Adrenal Chromaffin Cells
}

\author{
Atsushi NAKANISHI, Kyoji MORITA* and Motoo OKA \\ Department of Pharmacology, Tokushima University School of Medicine, \\ 3-18-15 Kuramoto. Tokushima 770. Japan \\ Accepted October 12, 1987
}

\begin{abstract}
The effect of the metabolic inhibitor 2,4-dinitrophenol (DNP) on the concentration of cytoplasmic ATP and the activity of catecholamine secretion was studied using cultured bovine adrenal chromaffin cells. The pretreatment of the cells with DNP resulted in a decrease in the concentration of cytoplasmic ATP. Catecholamine secretion evoked by either carbamylcholine or high $\mathrm{K}^{+}$was also reduced by DNP pretreatment. Oligomycin caused a significant decrease in both cytoplasmic ATP concentration and catecholamine secretion. In contrast, neither the ATP level nor the secretory response was affected by 2 -deoxyglucose. Similarly, catecholamine release from digitonin-permeabilized chromaffin cells in response to a direct calcium challenge was reduced by pretreatment of the cells with DNP, and this reduction was partially prevented by the presence of ATP in the permeabilizing medium. These results suggest that ATP in the cell cytoplasm may play an important role in the regulation of catecholamine secretion as a factor modulating the activity of the exocytotic process in the adrenal chromaffin cell.
\end{abstract}

The properties of catecholamine secretion from adrenal medulla have been extensively studied to obtain information about the exocytotic process, which is generally considered to involve secretory mechanisms of various neurotransmitters and hormones. It is well established that the exocytotic process of catecholamine secretion is initiated by a rise in the cytoplasmic concentration of free calcium (1) following the calcium influx into the cells after stimulation of the plasma membrane (2-4). In addition, it has also been proposed that metabolic energy besides calcium ions is also required for the exocytotic secretion (5, 6). However, the detailed mechanisms and sites of the actions of these factors have been poorly elucidated. In particular, since there has been no appropriate method for the selective determination of the concentration of ATP in the cell cytoplasm, it may therefore be fair to say that a possible involvement of cytoplasmic ATP in the exo-

- To whom correspondence should be addressed. cytotic process of catecholamine secretion is still in question.

New experimental procedures for permeabilizing the plasma membranes of chromaffin cells without interfering with their secretory function have recently been devised, and a crucial role of calcium ion in the exocytotic process has been confirmed (7-11). While, a possible requirement of ATP for the exocytotic secretion has been investigated using these permeabilized cell models, and catecholamine release evoked by a direct calcium challenge from electrically permeabilized chromaffin cells has been shown to be absolutely dependent on the presence of exogenous Mg-ATP (7, 8). In contrast, the release from the chemically permeabilized cells has been reported to show a partial requirement for exogenous ATP $(9-11)$. In addition to the earlier finding that the secretory response of cloned rat pheochromocytoma (PC12) cells is not influenced by reducing the cellular ATP content (12), it has recently been reported that dopamine release 
from PC12 cells permeabilized with staphylococcal $\alpha$-toxin is probably independent of exogenous ATP (13). These findings therefore seemed to provide evidence against a possible requirement of ATP for the exocytotic process of catecholamine secretion in PC1 2 cells. More recently, it has been shown that exogenous ATP is probably required for catecholamine release from $\alpha$-toxin-permeabilized chromaffin cells (14) as well as digitonin-permeabilized PC12 cells (15). The discrepancy of these findings seems to indicate that the difference in either the cell line or the permeabilizing method may exert a critical influence on the results of the experiments. Thus, conclusive evidence for a requirment of ATP in the exocytotic secretion has not yet been obtained from these permeabilized cell models

To elucidate the physiological importance of cytoplasmic ATP in the exocytotic mechanism, it is necessary to show a relationship between an alteration in the secretory activity of the chromaffin cell and that in the ATP content in the cell cytoplasm. For this purpose. the selective permeabilization of the plasma membrane by digitonin treatment, allowing cytoplasmic ATP to diffuse out, was employed to determine the concentration of ATP in the cytoplasmic space of the chromaffin cell. In the present study, we have found that the pretreatment of cultured chromaffin cells with metabolic inhibitors results in a decrease in the cytoplasmic concentration of ATP and a concomitant decline in the secretory activity of the cells. These findings suggest that the concentration of ATP in the cell cytoplasm has a physiologically important role as a possible factor regulating the exocytotic process of catecholamine secretion in the adrenal chromaffin cell.

\section{Materials and Methods}

Cell preparation and culture: Chromaffin cells were enzymatically prepared from fresh bovine adrenal glands according to the method described by Schneider et al. (16) with minor modifications. Briefly, the glands were perfused with balanced salt solution consisting of $135 \mathrm{mM} \mathrm{NaCl}, 5.6 \mathrm{mM} \mathrm{KCl}, 1.2$ $\mathrm{mM} \mathrm{MgSO}_{4}, 2.2 \mathrm{mM} \mathrm{CaCl}_{2}, 10 \mathrm{mM}$ glucose and $20 \mathrm{mM}$ 4-(2-hydroxyethyl) -1 - piperazine- ethanesulfonic acid (HEPES)/ $\mathrm{NaOH}(\mathrm{pH} 7.4$ ). The medullae were then sliced with a hand slicer instead of cut into fine pieces. These slices were sequentially digested in the medium containing $0.1 \%$ collagenase. $0.01 \%$ trypsin inhibitor and $0.5 \%$ bovine serum albumin in balanced salt solution. Cells were plated on 24-well plastic cluster plates (Costar, Cambridge, MA, U.S.A.) at a density of $5 \times 10^{5}$ cells/well and maintained for 3 days as monolayer primary cultures in $1.5 \mathrm{ml}$ of Eagle's minimum essential medium containing $5 \%$ heat-inactivated calf serum, $2 \mathrm{mM}$ glutamine, 100 units $/ \mathrm{ml}$ of penicillin. 100 $\mu \mathrm{g} / \mathrm{ml}$ of streptomycin, $40 \mu \mathrm{g} / \mathrm{ml}$ of gentamicin, $2.5 \mu \mathrm{g} / \mathrm{ml}$ of fungizone and $10 \mu \mathrm{M}$ cytosine arabinoside.

Cytoplasmic ATP in cultured adrenal chromaffin cells: Cells were pretreated with DNP at $37^{\circ} \mathrm{C}$ for $30 \mathrm{~min}$ in $250 /$ l of the glucose-free balanced salt solution; and then they were incubated with digitonin at $37^{\circ} \mathrm{C}$ for $10 \mathrm{~min}$ in $500 \mu \mathrm{l}$ of the calcium-free permeabilizing medium consisting of $140 \mathrm{mM}$ monosodium glutamate, $20 \mathrm{mM}$ 1,4-piperazinediethanesulfonic acid (PIPES) $/ \mathrm{NaOH}$ ( $\mathrm{pH}$ 6.8), 20 " $\mathrm{M}$ digitonin, $5 \mathrm{mM}$ glucose, $5 \mathrm{mM} \mathrm{MgSO}_{4}$ and $5 \mathrm{mM} \mathrm{EGTA}$. The amount of ATP released into the medium during the permeabilization period, which may reflect the ATP content in the cell cytoplasm, was then determined using luciferin-luciferase as described by Stanley and Williams (17). The cytoplasmic concentration of ATP was estimated according to the calculation method reported by Rojas et al. (18) on the basis of the assumption that the volume of the cell cytoplasm was $50 \%$ of the total cell volume. i.e., $2.5 \times 10^{-10} \mathrm{~cm}^{3}$.

Catecholamine secretion from intact adrenal chromaffin cells: Cells were pretreated with DNP at $37^{\circ} \mathrm{C}$ for $30 \mathrm{~min}$ in $250 \mu$ of the glucose-free balanced salt solution, and then they were incubated further at $37^{\circ} \mathrm{C}$ for 10 min in the same volume of balanced salt solution containing secretagogues without the inhibitor. The medium covering the cells was withdrawn at the end of the incubation period, and the cells were lysed by adding $250 \mu 1$ of $10 \%$ acetic acid and by subjecting them to a freeze-thaw cycle. Both medium and lysate were then centrifuged in an Ep- 
pendorf microfuge (type 5413) at the max mum speed (approx. $8800 \times \mathrm{g}$ ) for $2 \mathrm{~min}$, and the supernatant fractions were saved for catecholamine assay.

Catecholamine release from permeabilized adrenal chromaffin cells: The cells pretreated with DNP were incubated with digitonin at $37^{\circ} \mathrm{C}$ for $10 \mathrm{~min}$ in $250 \mu$ of the permeabilizing medium containing $5 \mathrm{mM}$ EGTA plus 5 $\mathrm{mM} \mathrm{CaCl} 2$. The medium was withdrawn, and the cells were lysed as described above. Both medium and cell lysate were centrifuged, and the supernatant fractions were saved for the determination of catecholamine release. The free calcium concentration calculated according to the method of portzehl et al. (19) was approximately $1 \mathrm{nM}$ in the calcium-free medium and $20 \mu \mathrm{M}$ in the calcium-containing medium, which corresponded to the values obtained from the actual measurement using a calcium electrode. The free calcium concentration was not significantly influenced by the presence of ATP in the permeabilizing medium, as reported previously (10).

Catecholamines in the supernatant fractions were determined by the modified trihydroxyindole method as described previously $(20,21)$.

Student's $t$-test was used to determine the statistical significance of differences between the means of groups.

Materials: Digitonin was purchased from Calbiochem-Behring (La Jolla, CA, U.S.A.). Collagenase (Type I), soybean trypsin inhibitor, bovine serum albumin (Fraction $V$ ). luciferase-luciferin, 2-deoxyglucose, oligomycin, and carbamylcholine were obtained from Sigma Chemical Co. (St. Louis, MO. U.S.A.). A23187 was obtained from the Aldrich Chemical Co. (Milwaukee, WI. U.S.A.). HEPES, PIPES and EGTA were obtained from Dohjin Chemica! Institute (Kumamoto, Japan). Other chemicals used were of the commercially available reagent grade.

\section{Results}

Effects of metabolic inhibitors on cytoplasmic ATP level and catecholamine secretion in cultured adrenal chromaffin cells: Cultured chromaffin cells were treated with a low concentration of digitonin in the calcium-free permeabilizing medium, and the amount of ATP released into the medium, which might reflect the cytoplasmic concentration of ATP. was determined. The amount of releasable ATP from these permeabilized cells was calculated as $193.5 \pm 11.9$ pmoles/ $10^{6}$ cells, and the total cellular ATP content was $3798.5 \pm 328.8$ pmoles $/ 10^{6}$ cells. The cytoplasmic concentration of ATP in the chromaffin cell was then estimated as approximately $0.8 \mathrm{mM}$. In view of the fact that approximately $60-70 \%$ of the cells in the preparations are chromaffin cells, these values obtained from our experiments seemed to correspond very well to that reported previously (19)

To examine the selective effect of a metabolic inhibitor on the cytoplasmic level of ATP in intact adrenal chromaffin cells, the cells were pretreated with various concentrations of DNP in the glucose-free medium, and the concentration of cytoplasmic ATP in these metabolically poisoned cells was then determined using the permeabilization

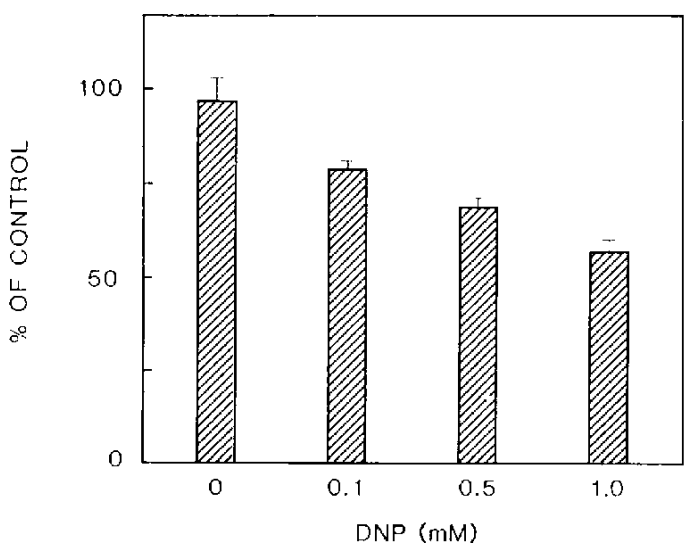

Fig. 1. Effect of DNP pretreatment on the amount of ATP released from chromaffin cells by permeabilization of the plasma membrane. Cells were pretreated with various concentrations of DNP at $37^{\circ} \mathrm{C}$ for 30 min, and then incubated with digitonin at $37^{\circ} \mathrm{C}$ for $10 \mathrm{~min}$ in the calcium-free medium. The amount of ATP released during the permeabilization period was determined as described in the text. Results were expressed as a percentage of the control value, which was the amount of ATP released from the untreated cells. Statistically significant change was observed at all the concentrations of DNP used ( $P<0.005)$. Values are the mean \pm S.D. of nine experiments. 
technique. As shown in Fig. 1, the pretreatment of the cells with DNP resulted in a marked decrease in the amount of ATP released into the medium from the permeabilized cells, and this reduction was observed in a concentration-dependent manner. In contrast, there was no significant change in the ATP contents retained within the permeabilized cells (data not shown).

The secretory response of chromaffin cells to different types of secretagogues was studied after pretreating the cells with DNP under the same conditions, and catecholamine secretion evoked by either carbamylcholine or high $\mathrm{K}^{+}$was found to be markedly suppressed by DNP pretreatment in a manner dependent on the concentration of the inhibitor (Fig. 2), although the basal secre tion was not significantly affected by pretreatment of the cells with DNP (data not shown).

Furthermore, the effects of different types of metabolic inhibitors on the ATP content and the secretion were studied. As shown in Table 1, the pretreatment of the celis with oligomycin resulted in a decrease in both cytoplasmic ATP content and the secretion, whereas 2-deoxyglucose influenced neither the ATP content nor the secretory response. These results therefore seemed to indicate a correlation between the reduction of $\mathrm{cy}$ toplasmic ATP content and the suppression of the secretory response.

Effect of exogenous ATP on catecholamine release from digitonin-permeabilized adrenal chromaffin cells: To test further whether ATP in the cell cytoplasm may directly participate in the exocytotic process, the influence of DNP pretreatment on catecholamine release from digitonin-permeabilized chromaffin cells was examined in the presence and absence of ATP. As shown in Fig. 3, the pretreatment of the cells with DNP caused a concentration-

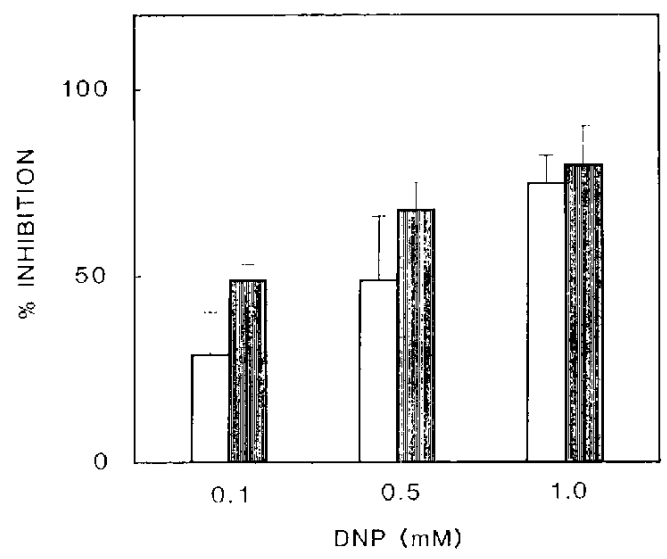

Fig. 2. Effect of DNP pretreatment on the secretion of catecholamines from chromaffin cells evoked by stimulation of the plasma membrane. Cells were pretreated with different concentrations of DNP at $37^{\circ} \mathrm{C}$ for $30 \mathrm{~min}$, and incubated further at $37^{\circ} \mathrm{C}$ for $10 \mathrm{~min}$ in the presence of either $100 \mu \mathrm{M}$ carbamylcholine (open column) or $56 \mathrm{mM} \mathrm{KCl}$ (closed column). The amount of catecholamines secreted during the second incubation was then determined as described in the text. Results were expressed as $\%$ inhibition of catecholamine secretion observed in the absence of DNP. Statistically significant inhibition of the secretion evoked by either carbamylcholine or high $\mathrm{K}^{+}$was observed by DNP pretreatmer.t at all the concentrations used $(P<0.005)$. Values are the mean \pm S.D. of six experiments.

Table 1. Cytoplasmic ATP content and catecholamine secretion in chromaffin cells pretreated with various metabolic inhibitors

\begin{tabular}{ccc}
\hline Metabolic inhibitor & $\begin{array}{c}\text { Cytoplasmic } \\
\text { ATP }\end{array}$ & $\begin{array}{c}\text { Catecholamine } \\
\text { secretion }\end{array}$ \\
\hline 2.4-Dinitrophenol $(1 \mathrm{mM})$ & $(\%$ of control $)$ & $(\%$ of control) \\
Oligomycin $(1 \mu \mathrm{g} / \mathrm{ml})$ & $50.7 \pm 3.2^{*}$ & $26.4 \pm 2.5^{*}$ \\
2-Deoxyglucose $(10 \mathrm{mM})$ & $82.9 \pm 1.5^{*}$ & $67.7 \pm 8.6^{*}$ \\
\hline
\end{tabular}

Cells were pretreated with different metabolic inhibitors at $37^{\circ} \mathrm{C}$ for $30 \mathrm{~min}$, and the amount of ATP released by permeabilization of the plasma membrane and catecholamine secretion evoked by $100 \mu \mathrm{M}$ carbamylcholine were determined as described in the text. Results were expressed as a percentage of the control values, which were obtained from the untreated cells. Values are the mean $\pm S$.D. of three experiments. "Difference from the control value was statistically significant $(P<0.005)$. 
dependent decrease in the release from the permeabilized cells in response to a direct

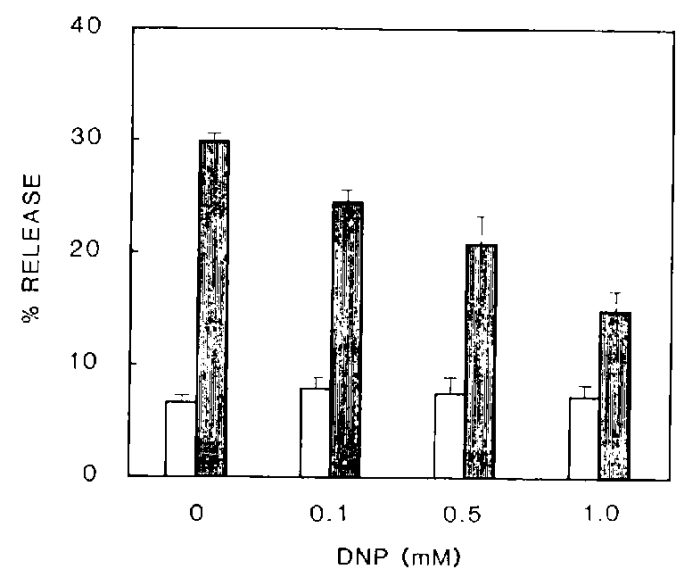

Fig. 3. Effect of DNP pretreatment on catecholamine release from digitonin-permeabilized chromaffin cells. Cells were preincubated with different concentrations of DNP at $37^{\circ} \mathrm{C}$ for $30 \mathrm{~min}$ and then permeabilized by incubating with digitonin at $37^{\circ} \mathrm{C}$ for $10 \mathrm{~min}$ in the presence (closed column) and absence (open column) of calcium ion. The amount of catecholamines released from the permeabilized cells was determined by the method described in the text. Results were expressed as the percentage of total cellular catecholamine content released during the permeabilization. Statistically significant decrease in the release evoked by calcium was observed by pretreatment of the cells with DNP at all the concentrations used $(P<0.005)$. Values are the mean $\pm S$.D. of six experiments. calcium challenge, whereas the calciumindependent release was not affected by DNP pretreatment. Furthermore, the influence of exogenous ATP on the calcium-dependent release from these metabolically poisoned permeabilized cells was also studied, and the suppression of the release caused by DNP pretreatment was partially prevented when ATP was present in the permeabilizing medium (Table 2). These findings therefore seemed to indicate a possible relationship between the concentration of cytoplasmic ATP and the activity of the exocytotic secretory system in these cells.

\section{Discussion}

In the previous studies, it has been reported that the plasma membranes of chromaffin cells can be selectively permeabilized by digitonin treatment without interfering with the functions of the chromaffin granule membrane $(22,23)$ as well as the exocytotic secretory function $(9,10)$, thus allowing the unrestricted diffusion of various soluble materials from the cytoplasmic space of these cells $(21,24)$. In view of these findings, it seems reasonable to assume that ATP released from digitonin-permeabilized chromaffin cells in the calcium-free medium may originate from the cytoplasmic space of these cells, thus reflecting the cytoplasmic concentration of ATP in the intact cell. In

Table 2. Effect of exogenous ATP on the suppression by DNP pretreatment of catecholamine release from digitonin-permeabilized chromaffin cells

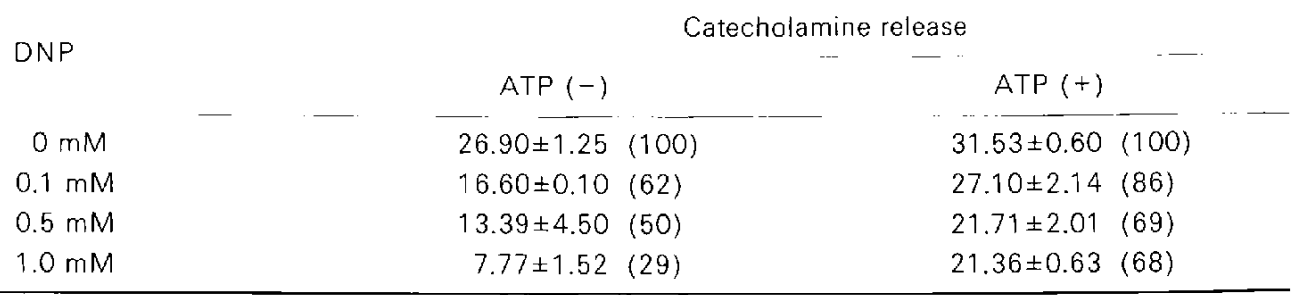

Cells were preincubated with different concentrations of DNP at $37^{\circ} \mathrm{C}$ for $30 \mathrm{~min}$, and then permeabilized with digitonin at $37^{\circ} \mathrm{C}$ for $10 \mathrm{~min}$ in the presence and absence of $5 \mathrm{mM} \mathrm{ATP}$. The amount of catecholamines released from the permeabilized cells was measured as described in the text. Results were calculated by subtracting the values obtained in the absence of calcium from that obtained in the presence of calcium, and they were expressed as a percentage of the total celiular catecholamine content released during the permeabilization. The suppression of the release by DNP was expressed as the \% of the control and given in parentheses. Difference in the suppression observed in the presence and absence of exogenous ATP was statistically significant at all the concentrations of DNP used $(P<0.005)$. Values are the mean $\pm S$. D. of three experiments. 
the present study, the pretreatment of chromaffin cells with DNP resulted in a decrease in the amount of ATP released from the cells by permeabilization of their plasma membranes with digitonin (Fig. 1). Furthermore, the suppression of catecholamine secretion evoked by either carbamylcholine or high $\mathrm{K}^{+}$was also observed by pretreatment of the cells with the inhibitor (Fig. 2). These results therefore suggest that the reduction of ATP content in the cell cytoplasm may be closely related to the suppression of catecholamine secretion. This possibility seems to be confirmed by the fact that the reduction of cytoplasmic ATP caused by the metabolic inhibitors is accompanied by the suppression of the secretory response (Table 1).

Both the ATP content and the secretory response of chromaffin cells were affected by pretreatment of the cells with either DNP or oligomycin, but the effects of these metabolic inhibitors on the ATP content were observed to be less pronounced than that on the secretion. These results seem to indicate that the reduction of a large portion of cytoplasmic ATP is not necessarily required for the suppression of catecholamine secretion. It seems possible to assume that only a small portion of the cellular ATP. which is probably present in the cytoplasmic compartment connected closely with the secretory mechanism, may be required for exhibiting the full activity of the secretory mechanism.

The experiments using intact chromaffin cells showed that the pretreatment of the cells with metabolic inhibitors resulted in the suppression of catecholamine secretion evoked by different types of secretagogues as well as the reduction of cytoplasmic ATP level, thus suggesting a possible involvement of cytoplasmic ATP in the intracellular secretory mechanism. However, since it has recently been suggested that calcium uptake into pancreatic islet cells is impaired by metabolic inhibitors presumably through their actions on the plasma membrane (25), the results obtained from the intact cells seem insufficient to exclude the possibility that metabolic inhibitors may cause the inhibition of catecholamine secretion as a result of an alteration in the functions of the plasma membrane rather than the activity of the exocytotic secretory process. To answer this question. we then examined the influence of DNP pretreatment on catecholamine release from digitoninpermeabilized chromaffin cells, in which the release may directly reflect the activity of the exocytotic process. Consequently, catecholamine release from these permeabilized cells in response to a calcium challenge was markedly reduced by pretreatment of the cells with DNP (Fig. 3), and this reduction was prevented by the presence of exogenous ATP (Fig. 4). These results therefore seem to indicate that the suppression of catecholamine release observed in these metabolicalIy poisoned permeabilized cells may directly reflect an alteration in the activity of the exocytotic secretory system, thus providing the first evidence for a physiologically important role of cytoplasmic ATP as a factor regulating the secretory activity of the adrenal chromaffin cell.

\section{References}

1 Knight, D.E. and Kesteven, N.T.: Evoked transient intracellular free $\mathrm{Ca}^{2+}$ changes and secretion in isolated bovine adrenal medullary cells. Proc. $R$. Soc. Lond. [Biol.] 218, 177-199 (1983)

2 Douglas, W.W. and Poisner, A.M.: Stimulation of uptake of calcium-45 in the adrenal gland by acetylcholine. Nature 162, 1299 (1961)

3 Kilpatrick, D.L., Slepetis, R.J., Corcoran, J.J. and Kirshner. N.: Calcium uptake and catecholamine secretion by cultured bovine adrenal medulla cells. J. Neurochem. 38, 427-435 (1982)

4 Holz, R.W., Senter, R.A. and Frye, R.A.: Relationship between $\mathrm{Ca}^{2+}$ uptake and catecholamine secretion in primary dissociated cultures of adrenal medulla. J. Neurochem. 39, 635-646 (1982)

5 Kirshner, N. and Smith, J.W.: Metabolic requirements for secretion from the adrenal medulla. Life Sci. 8 (Part 1), 799-803 (1969)

6 Rubin, R.P.: The role of energy metabolism in calcium-evoked secretion from the adrenal medulla. J. Physiol. (Lond.) 206, 181-192 (1970)

7 Baker, P.F. and Knight, D.E.: Calcium control of exocytosis and endocytosis in bovine adrenal medullary cells. Philos. Trans. R. Soc. Lond. [Biol.] 296, 83-103 (1981)

8 Knight, D.E. and Baker, P.F.: Calcium-depen dence of catecholamine release from bovine adrenal medullary cells after exposure to intense electric fields. J. Membr. Biol. 68, 107-140 
(1982)

9 Wilson, S.P. and Kirshner, N.: Calcium-evoked secretion from digitonin-permeabilized adrenal medullary chromaffin cells. J. Biol. Chem. 258, 4994-5000 (1983)

10 Dunn, L.A. and Holz, R.W.: Catecholamine secretion from digitonin-treated adrenal medullary chromaffin cells. J. Biol. Chem. 258, 49894993 (1983)

11 Brooks, J.C. and Treml, S.: Catecholamine secretion by chemically skinned cultured chromaffin celis. J. Neurochem. 40, 468-473 (1983)

12 Reynolds, E.E., Melega, W.P. and Howard, B.D.: Adenosine 5'-triphosphate independent secretion from PC12 pheochromocytoma cells. Biochemistry 21, 4795-4799 (1982)

13 Ahnert-Hilger, G., Bhakdi, S. and Gratzl, M.: Minimal requirements for exocytosis: a study using PC12 cells permeabilized with staphylococcal $\alpha$-toxin. J. Biol. Chem. 260, 1273012734 (1985)

14 Bader, M.-F., Thierse, D., Aunis, D., AhnertHilger, G. and Gratzl, M.: Characterization of hormone and proteiri release from $\alpha$-toxinpermeabilized chromaffin cells in primary culture. J. Biol. Chem. 261, 5777-5783 (1986)

15 Peppers, S.C. and Holz, R.W.: Catecholamine secretion from digitonin-treated PC12 cells: Effects of $\mathrm{Ca}^{2+}$, ATP, and protein kinase $\mathrm{C}$ activators. J. Biol. Chem. 261, 14665-14669 (1986)

16 Schneider, A.S., Herz, R. and Rosenheck, K.: Stimulus-secretion coupling in chromaffin cells isolated from bovine adrenal medu!la. Proc. Natl. Acad. Sci. U.S.A. 74, 5036-5040 (1977)

17 Stanley, P.E. and Williams, S.G.: Use of the liquid scintillation spectrometer for determining adenosine triphosphate by the luciferase enzyme. Anal. Biochem. 29, 381-392 (1969)
18 Rojas, E., Pollard, H.B. and Heldman, E.: Realtime measurements of acetylcholine-induced release of ATP from bovine medullary chromaffin cells. FEBS Lett. 185, 323-327 (1985)

19 Portzehl, H., Caldwell, P.C. and Rüegg, J.C.: The dependence of contraction and relaxation of muscle fibers from the crab Maia Squinado on the internal concentration of calcium ions. Biochim. Biophys. Acta 79, 581-591 (1964)

20 Morita, K., Brocklehurst, K.W., Tomares, S.M. and Pollard, H.B.: The phorbol ester TPA enhances A23187-but not carbachol- and high $\mathrm{K}^{+}$-induced catecholamine secretion from cultured bovine adrenal chromaffin cells. Biochem. Biophys. Res. Commun. 129, 511-516 (1985)

21 Morita, K., Levine, M., Heldman, E. and Pollard, H.B.: Ascorbic acid and catecholamine release from digitonin-treated chromaffin cells. J. Biol. Chem. 260, 15112-15116 (1985)

22 Holz, R.W. and Senter, R.A.: Plasma membrane and chromaffin granule characteristics in digitonin-treated chromaffin cells. J. Neurochem. 45, 1548-1557 (1985)

23 Morita, K., Levine, M. and Pollard, H.B.: Stimulatory effect of ascorbic acid on norepinephrine biosynthesis in digitonin-permeabilized adrenal medullary chromaffin cells. J. Neurochem. 46. 939-945 (1986)

24 Kelner, K.L., Morita, K., Rossen, J.S. and Pollard, H.B.: Restricted diffusion of tyrosine hydroxylase and phenylethanolamine $\mathrm{N}$-methyltransferase from digitonin-permeabilized adrenal chromaffin cells. Proc. Natl. Acad. Sci. U.S.A. 83, 2998-3002 (1986)

25 Nygren, P., Andersson, T. and Betsholtz, C.: Effects of metabolic inhibitors on the distribution of $45-\mathrm{Ca}$ in subcellular fractions from pancreatic islets. Biochem. Int. 10, 881-888 (1985) 